\title{
ANALISIS GAYA DAN MOMEN YANG TERJADI DI SEKITAR ELEMEN CHORD DAN BALOK KOLEKTOR AKIBAT GAYA GEMPA PADA BANGUNAN BERTINGKAT TINGGI
}

\author{
$\operatorname{Egan}^{1}$ dan Edison Leo ${ }^{2}$ \\ ${ }^{\text {I} P r o g r a m ~ S t u d i ~ S a r j a n a ~ T e k n i k ~ S i p i l, ~ U n i v e r s i t a s ~ T a r u m a n a g a r a, ~ J l . ~ L e t j e n ~ S . ~ P a r m a n ~ N o .1 ~ J a k a r t a ~}$ \\ Email: paturangsangegan@gmail.com \\ ${ }^{2}$ Program Studi Sarjana Teknik Sipil, Universitas Tarumanagara, Jl. Letjen S. Parman No.1 Jakarta \\ Email:edisonl@ft.untar.ac.id
}

\begin{abstract}
ABSTRAK
Indonesia merupakan negara berkembang yang sedang gencar melaksanakan pembangunan. Sebagai negara kepulauan, Indonesia juga terletak diantara 3 lempeng tektonik, yaitu lempeng Indo-Australian, lempeng Eurasia dan lempeng Pasific sehingga mengakibatkan Indonesia rawan terkena bencana gempa bumi. Dalam menghadapi goncangan seismik, bangunan harus di desain untuk bertindak sebagai satu kesatuan untuk menahan goncangan seismik. Sistem penahan gaya seismik terdiri dari elemen vertikal, elemen horizontal, dan pondasi. Elemen Horizontal umumnya terdiri dari diafragma, elemen chords, elemen kolektor. Diafragma memiliki fungsi sebagai penahan gaya gravitasi dan menyediakan tahanan lateral untuk elemen-elemen vertikal. Penelitian ini meneliti hasil analisis gaya dan momen yang terjadi di daerah elemen chords / balok kolektor akibat gaya gempa dengan menggunakan metode SNI 1726 : 2012 dan bantuan program ETABS 2016. Model yang digunakan adalah bangunan beraturan 8 lantai dengan sistem rangka bangunan dinding geser beton bertulang khusus yang terletak di Bekasi. Hasil analisis diperoleh, untuk elemen chords, pada daerah tarik diperlukan tulangan sedangkan daerah tekan tidak diperlukan tulangan. Untuk elemen kolektor balok b57, b59, b2 pada lantai 8, 7, dan 6 serta balok b27 pada lantai 8 diperlukan tulangan lentur. Untuk desain terhadap geser, diafragma tidak memerlukan tulangan geser.
\end{abstract}

Kata Kunci : Gaya seismik, Diafragma, Chords, Collector, tulangan

\section{PENDAHULUAN}

\section{Latar Belakang}

Indonesia merupakan negara berkembang yang sedang gencar melaksanakan pembangunan termasuk di kota-kota besar seperti Bekasi. Terbatasnya lahan yang ada serta meningkatnya kebutuhan akan perkantoran menjadikan fokus pembangunan pada era sekarang ini ialah bangunan bertingkat tinggi. Indonesia juga merupakan negara kepulauan yang terletak diantara 3 lempeng tektonik dunia, yaitu Lempeng Indo-Australian, Lempeng Eurasia dan Lempeng Pasific yang apabila bertemu dapat menghasilkan tumpukan energi yang memiliki ambang batas tertentu sehingga menjadikan Indonesia menjadi negara yang rawan akan terjadinya bencana bumi.

Sistem Struktur bangunan terbagi menjadi 2 macam, yaitu sistem struktur atas (balok, kolom, shearwall, pelat lantai) dan sistem struktur bawah (pondasi). Pada sistem struktur bawah, gaya gempa lateral yang terjadi langsung ditahan oleh pondasi, sedangkan pada sistem struktur atas, terbagi menjadi 2 elemen penahan gaya gempa lateral, yaitu oleh elemen vertikal struktur dan elemen horizontal struktur. Elemen vertikal struktur adalah semua elemen vertikal yang berada diantara pondasi dengan suatu level ketinggian yang bertugas menyalurkan beban gravitasi maupun gaya gempa dari lantai bangunan paling atas menuju pondasi. Sedangkan elemen horizontal struktur biasanya berupa diafragma seperti elemen chords dan elemen kolektor pada pelat lantai. Elemen chords merupakan daerah pada pelat lantai (tension / compression) yang terletak tegak lurus dengan arah gaya gempa yang terjadi sedangkan elemen kolektor merupakan daerah pada pelat lantai (bisa berupa balok) yang terletak searah dengan arah gaya gempa yang terjadi.

Mengacu pada gempa yang terjadi di Northridge, Los Angeles, tahun 1994, para ahli mengatakan hampir semua kegagalan struktur pada bangunan yang terjadi ialah kegagalan di daerah sambungan antara elemen chord dan balok kolektor dengan elemen vertikal (kolom maupun shearwall) sehingga dalam perencanaan diafragma sekarang ini harus menyertakan perhitungan gaya desain diafragma agar tidak terjadi kembali kegagalan pada daerah sambungan antara elemen chord dan balok kolektor dengan elemen vertikal (kolom maupun shearwall). 


\section{Batasan Masalah}

Dalam penyusunan makalah ini, ruang lingkup dan batasan masalah yang dibahas adalah:

1. Pemodelan struktur diasumsi oleh penulis dengan ukuran $20 \mathrm{~m} \mathrm{x} 20 \mathrm{~m}$ dibuat tanpa basement dan terdiri dari 8 lantai.

2. Gedung yang dimodelkan adalah gedung beraturan.

3. Gedung diasumsikan sebagai apartemen. Bangunan diasumsikan di kota Bekasi dengan jenis tanah lunak. Sistem penahan gaya seismik digunakan Sistem Rangka Bangunan dengan Dinding Geser Beton Bertulang Khusus.

4. Hasil output yang ditampilkan adalah analisis gaya normal, gaya geser, dan momen lentur yang terjadi akibat gaya gempa disekitar elemen chords dan balok kolektor.

5. Analisis yang ditinjau dalam 3 dimensi menggunakan bantuan program ETABS 2016.

6. Jenis perletakan yang digunakan adalah jepit.

7. Fungsi ruangan diabaikan.

8. Metode analisis beban gempa yang digunakan dalam penelitian ini adalah metode analisis statis dan metode analisis dinamik (analisis ragam respons spektrum).

\section{Rumusan Masalah}

Berdasarkan latar belakang di atas, maka masalah yang dirumuskan adalah sebagai berikut :

1. Bagaimana menghitung analisis gaya aksial yang terjadi akibat gaya gempa di sekitar elemen chords dan balok kolektor akibat gaya gempa pada diafragma dengan menggunakan program ETABS 2016?

2. Bagaimana menghitung analisis gaya geser yang terjadi akibat gaya gempa di sekitar elemen chords dan balok kolektor akibat gaya gempa pada diafragma dengan menggunakan program ETABS 2016?

3. Bagaimana menghitung analisis momen lentur yang terjadi akibat gaya gempa di sekitar elemen chords dan balok kolektor akibat gaya gempa pada diafragma dengan menggunakan program ETABS 2016?

\section{Tujuan Penelitian}

Tujuan dari penelitian ini adalah sebagai berikut :

1. Menghitung analisis gaya aksial yang terjadi akibat gaya gempa di sekitar elemen chords dan balok kolektor akibat gaya gempa pada diafragma.

2. Menghitung analisis gaya geser yang terjadi akibat gaya gempa di sekitar elemen chords dan balok kolektor akibat gaya gempa pada diafragma.

3. Menghitung analisis momen lentur yang terjadi akibat gaya gempa di sekitar elemen chords dan balok kolektor akibat gaya gempa pada diafragma.

\section{DASAR TEORI}

\section{Metode Analisis Beban Gempa}

Metode analisis statis ekivalen adalah suatu representasi dari beban gempa setelah disederhanakan dan dimodifikasi, dimana gaya inersia yang bekerja pada suatu massa akibat gempa disederhanakan menjadi gaya horizontal (Widodo, 2001). Menentukan besarnya gaya lateral akibat gaya gempa atau yang biasa disebut beban geser dasar (base shear) yang disimbolkan dengan $(V)$ sebagaimana diketahui beban gempa sesungguhnya bersifat dinamik yang berubah menurut waktu.

Metode analisis dinamik adalah suatu perhitungan beban gempa yang lebih kompleks perhitungannya dibanding metode analisis statis. Pada penelitian ini, metode analisis dinamik yang digunakan adalah analisis ragam spektrum respons (Response Spektrum Modal Analysis). Analisis ini digunakan untuk struktur gedung yang berperilaku elastis penuh, dimana pada suatu model matematik dari struktur diberlakukan suatu spektrum respons dari gempa rencana yang kemudian ditentukan respons struktur terhadap pengaruh suatu gempa melalui superposisi dari respons tiap ragamnya. Bila respons dinamik struktur gedung dinyatakan dalam gaya geser dasar $(V t)$, maka persyaratan tersebut dapat dinyatakan dengan persamaan berikut :

Keterangan :

$$
V t \geq 0,85 V 1
$$

$V 1=$ gaya geser dasar nominal sebagai respons ragam pertama atau yang didapat dari prosedur analisis gaya lateral ekivalen terhadap pengaruh gempa rencana. 
Oleh karena itu, berdasarkan SNI 03-1726-2012, gaya geser tingkat nominal akibat pengaruh gempa rencana sepanjang tinggi struktur gedung dari hasil analisis ragam respons spektrum dalam suatu arah tertentu harus dikalikan nilainya dengan suatu faktor skala, penetuan faktor skala dapat dihitung dari persamaan berikut :

Keterangan :

$$
\text { Faktor skala }=\frac{0,85 x V 1}{V} \geq 1
$$

$\mathrm{V} 1=$ gaya geser dari analisis gaya lateral ekivalen

$\mathrm{V} \quad$ = gaya geser dasar dari kombinasi ragam yang diisyaratkan

\section{Komponen Diafragma}

Macam bentuk-bentuk diafragma yaitu diafragma pelat, chords, kolektor (yang juga dikenal sebagai drag strutrs atau distributor) dan penyambung elemen vertikal. Perbedaan bentuk tersebut dapat di identifikasi berdasarkan beban yang bekerja pada diafragma. Gambar 1. mengilustrasikan model sederhana dari diafragma dalam menahan beban in plane.
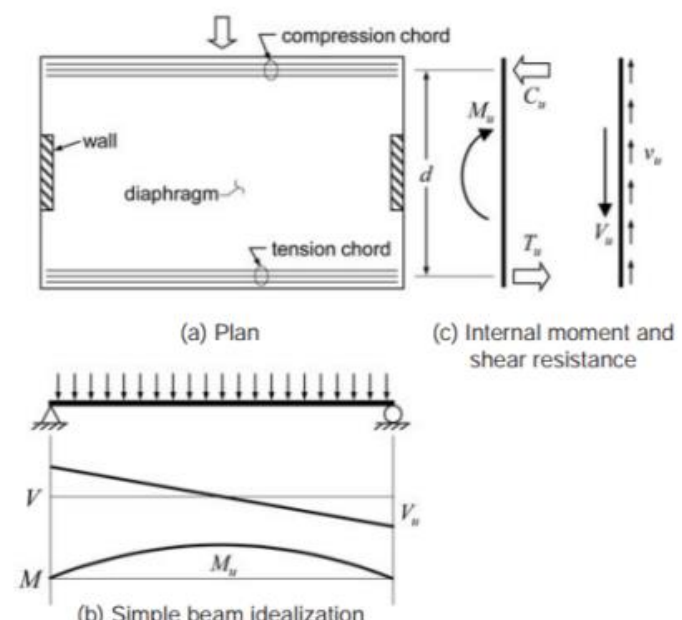

(b) Simple beam idealization

Gambar 1. Tension and Compression Chords

\section{Gaya Desain Diafragma}

Diafragma lantai dan atap harus didesain untuk menahan gaya gempa desain dari analisis struktur, tetapi tidak boleh kurang dari yang ditentukan sesuai dengan persamaan berikut :

Keterangan :

$$
\mathrm{Fpx}=\frac{\sum_{i=x}^{n} F i}{\sum_{i=x}^{n} w i} \mathrm{x} \mathrm{Wpx}
$$

Fpx = Gaya desain diafragma

$\mathrm{Fi} \quad=$ Gaya desain yang diterapkan di tingkat $\mathrm{i}$

$\mathrm{Wi}=$ Tributari berat sampai tingkat $\mathrm{i}$

Wpx = Tributari berat sampai diafragma di tingkat $\mathrm{x}$

Gaya yang ditentukan tidak boleh kurang dari :

$\mathrm{Fpx}=0.2 \times \mathrm{S}_{\mathrm{DS}} \mathrm{x}$ Ie $\mathrm{x} \mathrm{Wpx}$

dan tidak boleh melebihi :

$\mathrm{Fpx}=0.4 \times \mathrm{S}_{\mathrm{DS}} \mathrm{x}$ Ie $\mathrm{x}$ Wpx

\section{Desain Elemen Chords}

Gaya tarik dan tekan dari elemen chords dapat dihitung sebagai berikut :

$$
\mathrm{Cu}=\mathrm{Tu}=\frac{M u}{d}
$$

Dimana untuk tulangan non-prestress terkonsentrasi dekat tepi diafragma, persamaan untuk luas tulangan dari gaya tarik chord, menggunakan $\phi=0,9$, adalah :

$$
\text { As } \quad=\frac{T u}{\phi x f y}
$$


Sebelum edisi 2008, ACI 318, gaya tekan chords wajib menggunakan tulangan pengikat jika kuat tekan stress melebihi $0.2 \mathrm{f} \mathrm{c}$ '. Persyaratan ini dihilangkan di Edisi 2008 kecuali untuk elemen diafragma yang digunakan untuk mentransfer diafragma geser atau gaya lentur di sekitar pelat openings atau bangunan yang memiliki ketidakberaturan.

\section{Desain Geser Diafragma}

Setiap bagian dari diafragma harus di desain terhadap kekuatan geser (Vu) dimana desain tersebut tidak lebih besar dari desain geser terfaktor $(\phi \mathrm{Vn})$. Untuk diafragma yang memiliki tulangan chords di daerah tension, maka kekuatan geser terfaktor terdistribusi merata sepanjang lebar diafragma. Besar nilai $\phi=0.75$. Besar Vn dapat dihitung sesuai rumus berikut :

$$
\mathrm{Vn} \quad=0.66 \times \mathrm{Acv} \times \sqrt{f^{\prime} c}
$$

Penulangan geser dapat ditempatkan di mana saja di dalam pelat dengan batas selimut beton yang diperlukan. Beberapa ahli menentukan penulangan bawah yang terus menerus yang memenuhi persyaratan geser dan lentur diafragma. Jika hal ini dilakukan, maka luasan tulangan total adalah jumlah area diperlukan untuk momen dan geser.

\section{Desain Elemen Kolektor}

Persyaratan ini berlaku untuk komponen struktur rangka momen khusus yang membentuk bagian sistem penahan gaya gempa dan diproporsikan terutama untuk menahan lentur. Komponen struktur rangka ini juga harus menahan gaya tekan aksial :

$$
\mathrm{Pu} \leq 0.1 \times \mathrm{Ag} \text { x f'c }
$$

Jika sistem penahan gaya gempa dan yang menahan gaya tekan aksial terfaktor Pu akibat kombinasi beban melebihi 0.1 x Ag x f'c, maka penulangan lentur komponen struktur rangka ini harus memenuhi kondisi sebagai elemen kolom.

\section{METODOLOGI PENELITIAN}

Pada penelitian ini, dilakukan langkah-langkah sebagai berikut seperti gambar 2. :

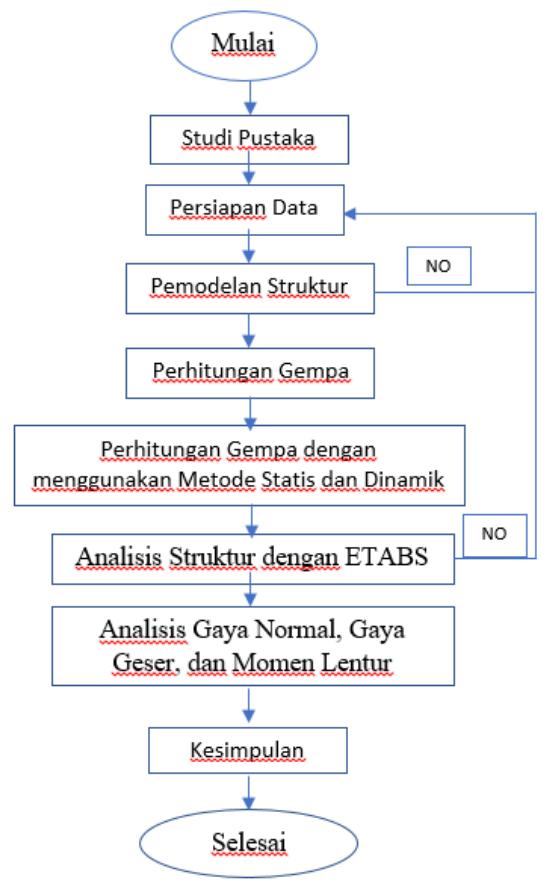

Gambar 2. Diagram Alir Penelitian 
Metodologi penelitian yang dilakukan pada skripsi ini adalah :

1. Studi Literatur

Pengumpulan teori yang mendukung untuk analisis elemen chord dan balok kolektor dengan panduan program ETABS

2. Pemodelan Struktur

Membuat model dan modifier bangunan yang digunakan dalam analisis sesuai dengan SNI 1726:2012

3. Perencanaan dan Analisis

Menghitung pradimensi penampang sesuai SNI 2847:2013, keberaturan gedung, dan gaya gempa desain yang digunakan sesuai SNI 1726:2012.

4. Hasil Penelitian

Hasil perhitungan konvensional dan ouput program ETABS

5. Analisis Hasil

Mengetahui kebutuhan tulangan pada daerah elemen chord dan balok kolektor akibat gaya gempa

\section{HASIL DAN ANALISIS}

\section{Analisis Beban Gempa}

Untuk pengecekan gedung beraturan, digunakan beban gempa berdasarkan analisis statis ekivalen karena gaya gempa berdasarkan analisis dinamik lebih kecil. Tabel analisis beban gempa dapat dilihat pada tabel 1.

Tabel 1. Analisis Beban Gempa

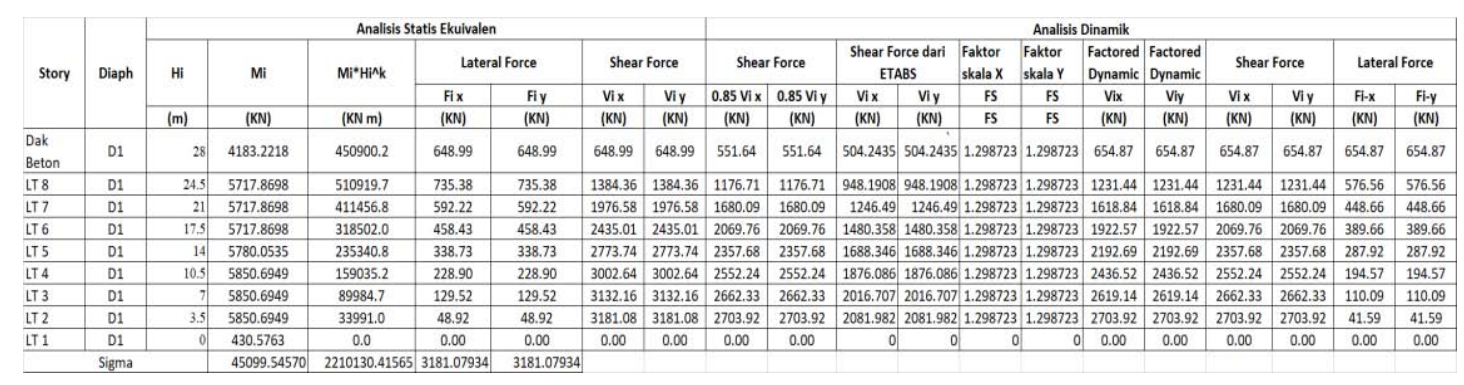

\section{Gaya Desain Diafragma}

Untuk pengecekan elemen chord dan balok kolektor, maka digunakan beban gempa desain diafragma sesuai tabel 2 yang di input kedalam ETABS sesuai dengan lantai yang sedang di tinjau.

Tabel 2. Gaya Desain Diafragma

\begin{tabular}{|c|c|c|c|c|c|c|c|c|c|c|c|c|c|}
\hline Story & Diafragma & Wi & Wi Kumulatif & Fi-x & Fi- $y$ & Fi-x Kumulatif & Fi-y Kumulatif & $F p x$ & Fpy & Fp min & Fp max & Fpx Desain & Fpy Desain \\
\hline & & & & & & & & & & & & & \\
\hline Beton & D1 & 4183.222 & 4183.2218 & 648.99 & 648.99 & 648.99 & 648.99 & 648.9885 & 648.9885 & 507.8431 & 1015.686253 & 648.9885084 & 648.9885084 \\
\hline LT 8 & D1 & 5717.87 & 9901.0916 & 735.38 & 735.38 & 1384.36 & 1384.36 & 799.4688 & 799.4688 & 694.1494 & 1388.298787 & 799.4688165 & 799.4688165 \\
\hline LT7 & $D 1$ & 17.87 & 15618.9614 & 592.22 & 592.22 & 776.58 & 1976.58 & 723.597 & 723.597 & 4.1494 & 1388.298787 & \begin{tabular}{|l|}
723.5969736 \\
\end{tabular} & 723.5969736 \\
\hline LT6 & D1 & 717.87 & 21336.8312 & 458.43 & 458.43 & 2435.01 & 2435.01 & 652.536 & 652.536 & 694.1494 & 1388.298787 & 652.5360039 & 652.5360039 \\
\hline LT5 & D1 & 30.054 & 116.8847 & 338.73 & 338.73 & 3.74 & 2773.74 & 591.2311 & 591.2311 & 701.6985 & 1.39699 & 591.2311388 & 591.2311388 \\
\hline LT4 & $D 1$ & 5850.695 & 32967.5796 & 228.90 & 228.90 & 3002.64 & 3002,64 & 532.8727 & 532.8727 & 710.2744 & 1420.548722 & \begin{tabular}{|l|}
532.8727225 \\
\end{tabular} & 532.8727225 \\
\hline LT3 & D1 & 5850.695 & 38818.2745 & 129.52 & 129.52 & 3132.16 & 3132.16 & 472.0788 & 472.0788 & 710.2744 & 1420.548722 & 472.0788344 & 472.0788344 \\
\hline LT2 & D1 & & & 48.92 & 48.92 & & & 416. & 416.6544 & 710.2744 & & 416.6544452 & 416.6544452 \\
\hline LT1 & D1 & 430.5763 & 45099.5457 & 0.00 & 0.00 & 3181.08 & 3181.08 & 30.37054 & 30.37054 & 52.27196 & 104.5439256 & 30.3705359 & 30.3705359 \\
\hline
\end{tabular}

\section{Hasil Penulangan Elemen Chord Akibat Gaya Gempa Terkombinasi Arah X}

Dilakukan section cut sebanyak 3 potongan, untuk akibat gaya gempa arah X sejarak 5m (gambar 3 dan 4), 10m ,dan $15 \mathrm{~m}$ dari pinggir kiri agar mendapatkan hasil gaya dan momen yang terjadi disekitar elemen chord dan balok kolektor. Jarak tulangan diambil 300mm. 


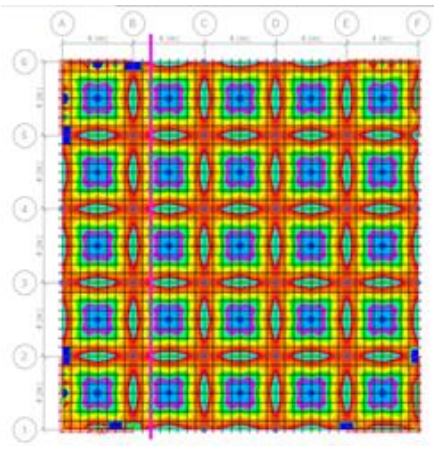

Gambar 3. Section Cut 1

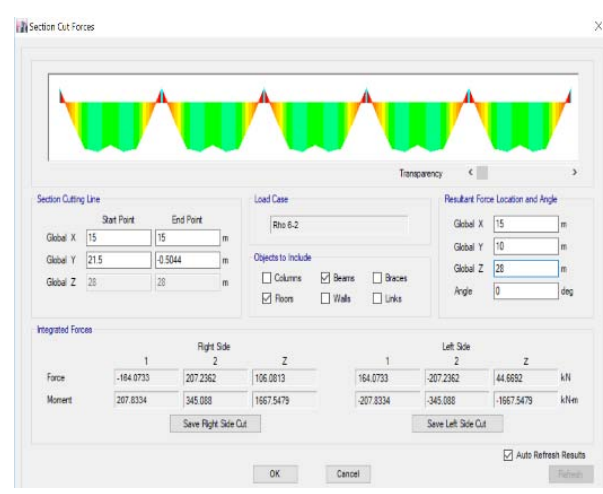

Gambar 4. Section Cut Forces 1

Hasil penulangan daerah tension elemen chord dapat dilihat pada tabel di bawah ini sedangkan untuk daerah compression tidak diperlukan tulangan dikarenakan bentuk bangunan yang merupakan bangunan beraturan.

Tabel 3. Penulangan daerah Tension

\begin{tabular}{|c|c|c|c|c|c|c|}
\hline \multicolumn{7}{|c|}{ CHORD } \\
\hline \multicolumn{7}{|c|}{ Tension } \\
\hline Lantai & Location Section Cut & $\mathrm{Mu} / \mathrm{d}(\mathrm{KN})$ & As $\left(m^{\wedge} 2\right)$ & $\begin{array}{c}\text { Diameter } \\
(\mathrm{mm})\end{array}$ & Tulangan & n Tulangan \\
\hline \multirow[b]{3}{*}{ Dak Beton } & 1 & 17.858535 & \begin{tabular}{|l|}
49.607042 \\
\end{tabular} & \begin{tabular}{|r|}
16 \\
\end{tabular} & 0.246850327 & 2 \\
\hline & 2 & 48.66344 & 135.17622 & 16 & 0.67265238 & 2 \\
\hline & 3 & 83.377285 & 231.60357 & 16 & 1.152485915 & 2 \\
\hline \multirow[b]{3}{*}{8} & 1 & 51.936295 & 144.26749 & 16 & 0.717891551 & 2 \\
\hline & 2 & 107.3471 & 298.18639 & 16 & 1.483809658 & 2 \\
\hline & 3 & 150.7575 & 418.77083 & 22 & 1.102202541 & 2 \\
\hline \multirow[b]{3}{*}{7} & 1 & 79.44505 & 220.68069 & 16 & 1.098132437 & 2 \\
\hline & 2 & 120.09571 & 333.59919 & 16 & 1.660027839 & 2 \\
\hline & 3 & 162.54965 & 451.52681 & 22 & 1.18841608 & 2 \\
\hline \multirow[b]{3}{*}{6} & 1 & 66.400325 & 184.44535 & 16 & 0.917821194 & 2 \\
\hline & 2 & 97.63832 & 271.21756 & 16 & 1.349609651 & 2 \\
\hline & 3 & 139.50826 & 387.52294 & 16 & 1.928358601 & 2 \\
\hline \multirow[b]{3}{*}{5} & 1 & 50.39427 & \begin{tabular}{|l|}
139.98408 \\
\end{tabular} & 16 & 0.696576848 & 2 \\
\hline & 2 & 68.589425 & 190.52618 & 16 & 0.948080118 & 2 \\
\hline & 3 & 112.76719 & 313.24218 & 16 & 1.558729004 & 2 \\
\hline \multirow[b]{3}{*}{4} & 1 & 26.31041 & 73.084472 & 16 & 0.363676713 & 2 \\
\hline & 2 & 41.70044 & 115.83456 & 16 & 0.576406029 & 2 \\
\hline & 3 & 82.799745 & 229.99929 & 16 & 1.144502845 & 2 \\
\hline \multirow[b]{3}{*}{3} & 1 & 6.422505 & \begin{tabular}{|l|}
17.840292 \\
\end{tabular} & 16 & 0.088775337 & 2 \\
\hline & 2 & 0.44643 & 1.2400833 & 16 & 0.006170797 & 2 \\
\hline & 3 & 41.948165 & 116.52268 & 16 & 0.579830218 & 2 \\
\hline \multirow[b]{3}{*}{2} & 1 & 61.022045 & 169.50568 & 16 & 0.8434797 & 2 \\
\hline & 2 & 7.590835 & 21.085653 & 16 & 0.104924626 & 2 \\
\hline & 3 & \begin{tabular}{|l|l}
22.038715 \\
\end{tabular} & 61.218653 & 16 & 0.304631035 & 2 \\
\hline
\end{tabular}

\section{Hasil Penulangan Elemen Chord Akibat Gaya Gempa Terkombinasi Arah Y}

Dilakukan section cut sebanyak 3 potongan, untuk akibat gaya gempa arah Y sejarak 5m (gambar 5 dan 6), 10m ,dan $15 \mathrm{~m}$ dari pinggir bawah agar mendapatkan hasil gaya dan momen yang terjadi disekitar elemen chord dan balok kolektor. Jarak tulangan diambil 300mm.

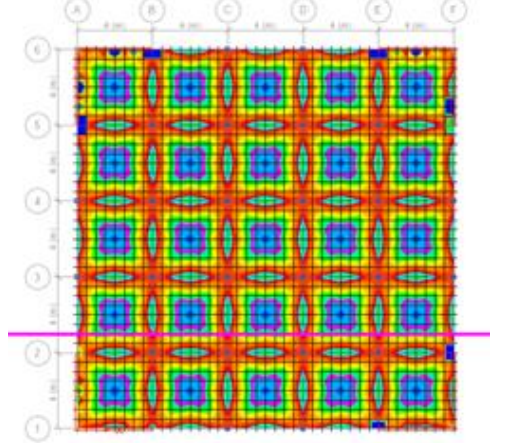

Gambar 5. Section Cut 1

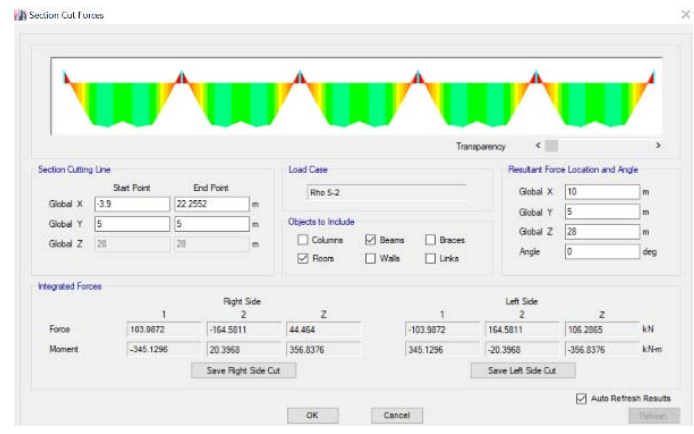

Gambar 6. Section Cut Forces 1 
Hasil penulangan daerah tension elemen chord dapat dilihat pada tabel di bawah ini sedangkan untuk daerah compression tidak diperlukan tulangan dikarenakan bentuk bangunan yang merupakan bangunan beraturan.

Tabel 4. Penulangan daerah Tension

\begin{tabular}{|c|c|c|c|c|c|c|}
\hline \multicolumn{7}{|c|}{ CHORD } \\
\hline \multicolumn{7}{|c|}{ Tension } \\
\hline Lantai & Location Section Cut & $\mathrm{Mu} / \mathrm{d}(\mathrm{KN})$ & $\begin{array}{c}\text { As } \\
\left(\mathrm{mm}^{\wedge} 2\right)\end{array}$ & $\begin{array}{l}\text { Diameter } \\
(\mathrm{mm})\end{array}$ & Tulangan & $\mathrm{n}$ Tulangan \\
\hline \multirow[b]{3}{*}{ Dak Beton } & 1 & 17.84188 & 49.56078 & 16 & 0.246620112 & 2 \\
\hline & 2 & 48.75329 & 135.4258 & 16 & 0.673894335 & 2 \\
\hline & 3 & 83.411165 & 231.6977 & 16 & 1.152954223 & 2 \\
\hline \multirow[b]{3}{*}{8} & 1 & 52.292025 & 145.2556 & 16 & 0.722808644 & 2 \\
\hline & 2 & 107.265895 & 297.9608 & 16 & 1.482687199 & 2 \\
\hline & 3 & 150.43141 & 417.865 & 22 & 1.099818465 & 2 \\
\hline \multirow[b]{3}{*}{7} & 1 & 78.784735 & 218.8465 & 16 & 1.089005206 & 2 \\
\hline & 2 & 119.96575 & 333.2382 & 16 & 1.658231461 & 2 \\
\hline & 3 & 162.901825 & 452.5051 & 22 & 1.190990866 & 2 \\
\hline \multirow[b]{3}{*}{6} & 1 & 64.110075 & 178.0835 & 16 & 0.886164121 & 2 \\
\hline & 2 & 97.23866 & 270.1074 & 16 & 1.344085335 & 2 \\
\hline & 3 & 141.12983 & 392.0273 & 16 & 1.950772818 & 2 \\
\hline \multirow[b]{3}{*}{5} & 1 & 56.362965 & 156.5638 & 16 & 0.779079377 & 2 \\
\hline & 2 & 67.62558 & 187.8488 & 16 & 0.934757331 & 2 \\
\hline & 3 & 109.497305 & 304.1592 & 16 & 1.513530954 & 2 \\
\hline \multirow[b]{3}{*}{4} & 1 & 25.2513 & 70.1425 & 16 & 0.349037122 & 2 \\
\hline & 2 & 40.59684 & 112.769 & 16 & 0.561151473 & 2 \\
\hline & 3 & 83.94807 & 233.1891 & 16 & 1.160375614 & 2 \\
\hline \multirow[b]{3}{*}{3} & 1 & 9.85989 & 27.38858 & 16 & 0.136288731 & 2 \\
\hline & 2 & 1.460345 & 4.056514 & 16 & 0.020185678 & 2 \\
\hline & 3 & 43.467185 & 120.7422 & 16 & 0.600826933 & 2 \\
\hline \multirow[b]{3}{*}{2} & 1 & 59.26024 & 164.6118 & 16 & 0.819127079 & 2 \\
\hline & 2 & 8.418365 & 23.38435 & 16 & 0.116363193 & 2 \\
\hline & 3 & 22.970225 & \begin{tabular}{|l|l|}
63.80618 \\
\end{tabular} & 16 & 0.31750687 & 2 \\
\hline
\end{tabular}

\section{Penulangan Geser}

Untuk menghitung penulangan geser akibat gaya gempa terkombinasi arah X (tabel 5) dan Y (tabel 6) diambil section cut yang menghasilkan gaya F22 terbesar, yaitu pada jarak $10 \mathrm{~m}$ dari pinggir kiri dan bawah.

Tabel 5. Penulangan Geser Diafragma

\begin{tabular}{|c|c|c|c|c|c|c|c|}
\hline \multicolumn{8}{|c|}{ Shear Reinforcement Checking } \\
\hline \multirow[b]{2}{*}{ Lantai } & \multirow[b]{2}{*}{ Location } & \multirow[b]{2}{*}{ l.m) } & \multirow[b]{2}{*}{$V_{0}([22) \mid(K N)$} & \multirow[b]{2}{*}{ Vu/phi $(\mid X N)$} & \multirow{2}{*}{$\begin{array}{c}\text { Concetete Shear } /(\mathrm{Wn}) \\
(\mathrm{NN})\end{array}$} & \multirow{2}{*}{$\begin{array}{c}\text { | Shear Reinforcement||VS| } \\
\qquad|\mathrm{NN}|\end{array}$} & \multirow{2}{*}{$\begin{array}{l}\text { Reinforcement Neede } \\
\left(\left[\mathrm{m}^{\prime \prime} / \mathrm{m}\right)\right.\end{array}$} \\
\hline & & & & & & & \\
\hline & $8 \quad 2$ & 220 & 297.085 & 396.113333 & 6778.066649 & TIDAK PERLU & TIDARPERU \\
\hline & 7 & 2 & 207.2362. & 276.344933 & 6778.066649 & TIDAKPERLU & TIDAK PERLU \\
\hline & 6 & 2 & 224,4828 & 299.3104 & 6778.066649 & TDAARPER,U & TIDAK PERLU \\
\hline 5 & 5 & 2 & 339.3944 & 452.525467 & 6778.066649 & TIDAK PERLU & TIDAKPERLU \\
\hline & 4 & 2 & 351.6511. & 468.868133 & 6778.066649 & TIDAK PERLU & TIDAKPERLU \\
\hline 3 & 3 & 2 & 162.589 & 216.785333 & 6778.066649 & TDAR PERLU & TIDARPERLV \\
\hline 2 & 2 & 20 & 279.8925 & 373,19 & 6778.066649 & TIDAKPERLU & TIDAK PERLV \\
\hline 1 & 1 & 20 & 277.8123 & 370.464 & 6778.066649 & TIDAK PERLU & TIDAK PERLU \\
\hline
\end{tabular}

Tabel 6. Penulangan Geser Diafragma

\begin{tabular}{|c|c|c|c|c|c|c|}
\hline \multicolumn{7}{|c|}{ Shear Reinforcementchecking } \\
\hline \multirow[b]{2}{*}{ lantai } & \multirow[b]{2}{*}{ Location } & \multirow[b]{2}{*}{$\lfloor(m)$} & \multirow[b]{2}{*}{$\operatorname{Vu}(F 22)(\mathrm{KN})$} & \multirow{2}{*}{ 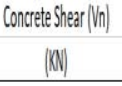 } & \multirow{2}{*}{ 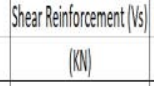 } & \multirow{2}{*}{$\begin{array}{c}\text { Reniforcementillededed } \\
{[\mathrm{cm} \cdot 2 / \mathrm{m} \mid}\end{array}$} \\
\hline & & & & & & \\
\hline & $8 \quad 2$ & 20 & 1058:0359 14107.745 & 6778.066069 & TIDAY PERRU & TDAAPPRRU \\
\hline & 7 & 20 & $654,5412.8727216$ & 6778.0666649 & TIDAY PERLU & TDAR PERR \\
\hline & 6 & 20 & $1059,392611412.52525$ & 6778.066069 & TIDAY PERLU & TIDAK PERLU \\
\hline & 5 & 20 & 1005.6302 1340.8403 & 6778.066649 & TIDAK PERU & TDAK PERLU \\
\hline & 4 & 20 & 1073.3666 1431.150: & 6778,0660649 & TIDAM PERLU & TIDAK PERLU \\
\hline & 3 & 20 & 897.077 1966.0627 & 6778.0666649 & TIDAY PERLU & TDAR PERLU \\
\hline & 2 & 20 & 8933.4888 1919.1.1317 & 6778.066069 & TIDAK PERLU & TIDAK PERLU \\
\hline & 1. & 20 & 877.8621 .1166 .4828 & 6778.0666049 & TIDAK PFRRU & TIDAK PRRPU \\
\hline
\end{tabular}

\section{Pengecekan Elemen Balok Kolektor}

Untuk Gaya Gempa arah X, balok yang ditinjau sebagai elemen kolektor ialah balok B32, B33, B34, B36, B37, B38, B39, B40, B51, B52, B53, B54, B55, B57, B58, B59 dengan kombinasi beban terbesar akibat beban gempa arah X didapat yaitu. 1.3214 DL + LL - 2.5 EQX + 0.75 EQY (lihat gambar 7). Untuk Gaya Gempa arah Y, balok yang ditinjau sebagai elemen kolektor ialah balok B2, B3, B4, B6, B7, B8, B9, B10, B21, B22, B23, B24, B25, B27, B28, B29 dengan kombinasi beban terbesar akibat beban gempa arah X didapat yaitu. 1.3214 DL + LL - 0.75 EQX +2.5 EQY (lihat gambar 8). 


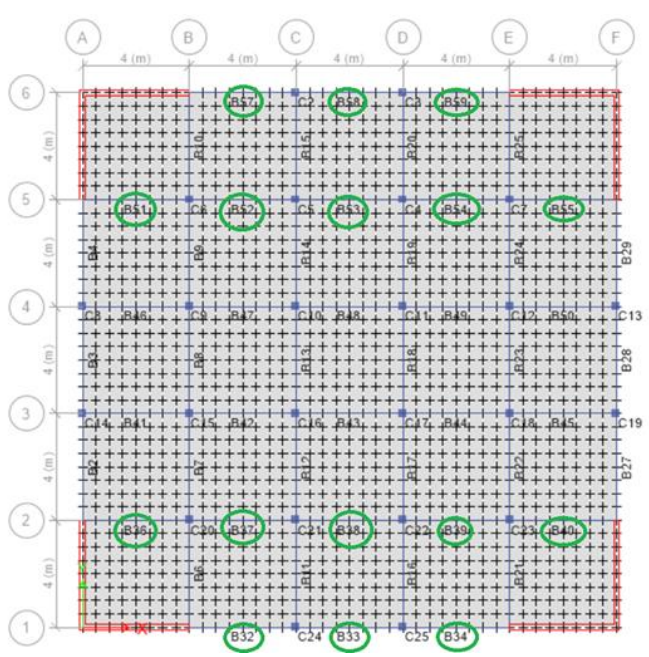

Gambar 7. Balok Kolektor arah X

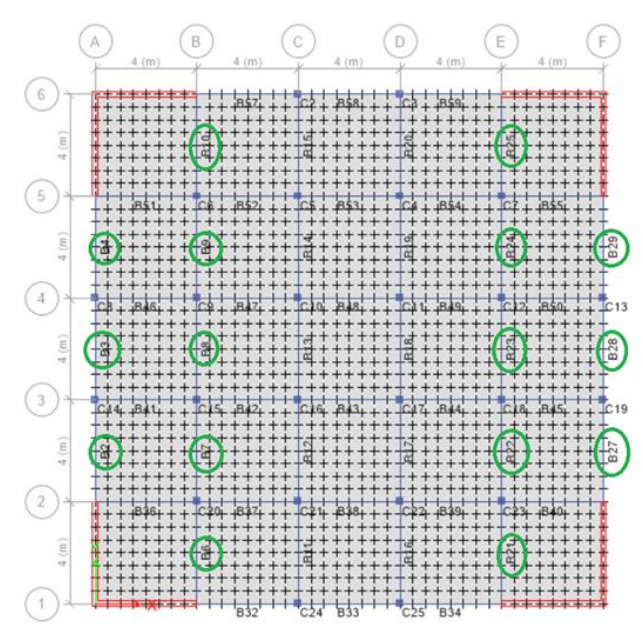

Gambar 8. Balok Kolektor arah Y

Tabel 7. Penulangan Balok Kolektor akibat gaya gempa arah X
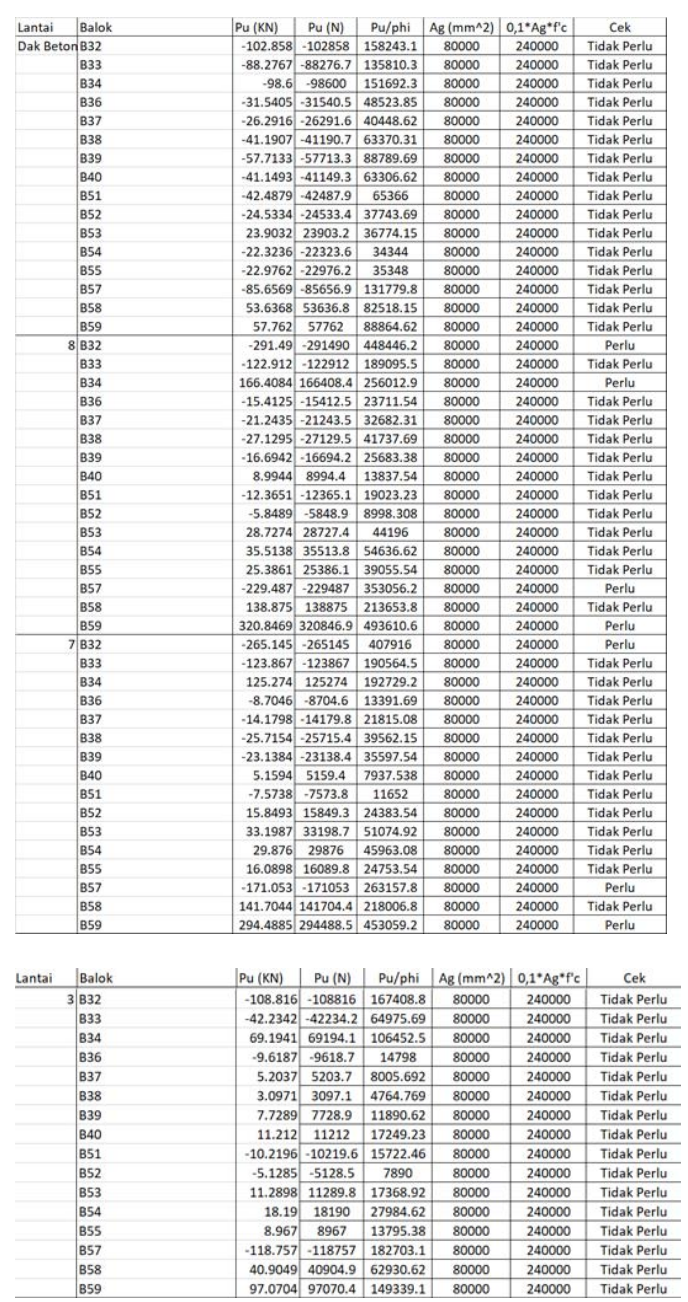
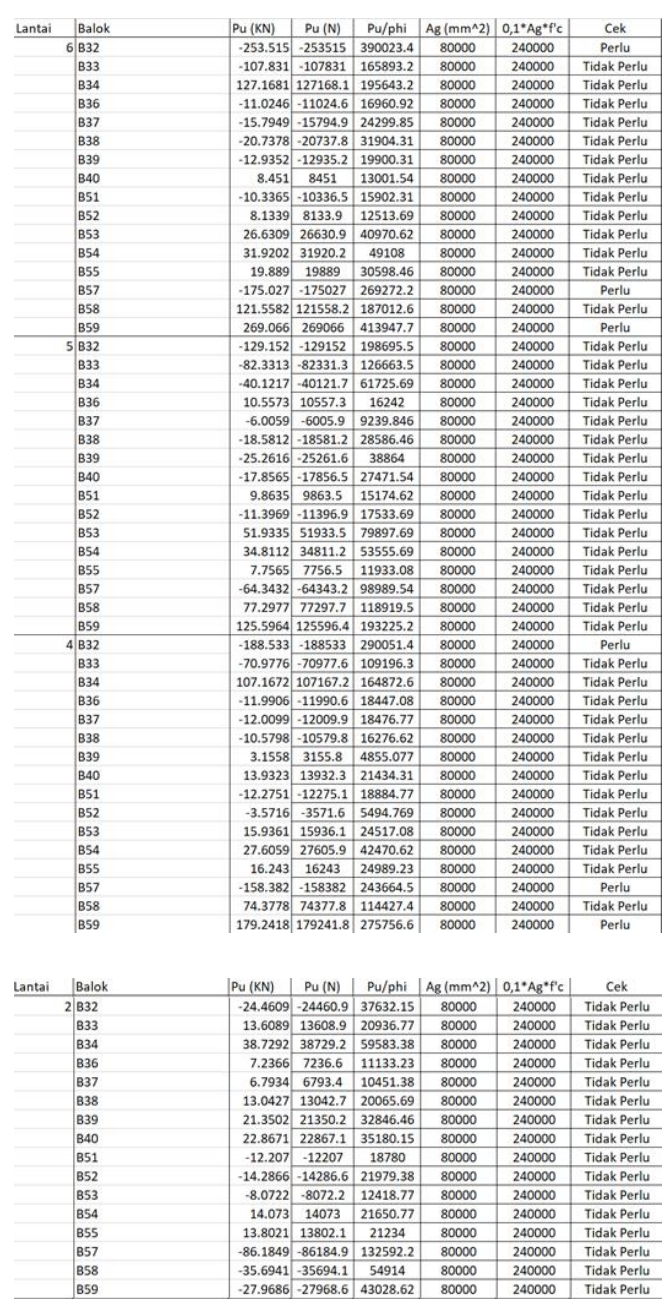
Tabel 8. Penulangan Balok Kolektor akibat gaya gempa arah Y

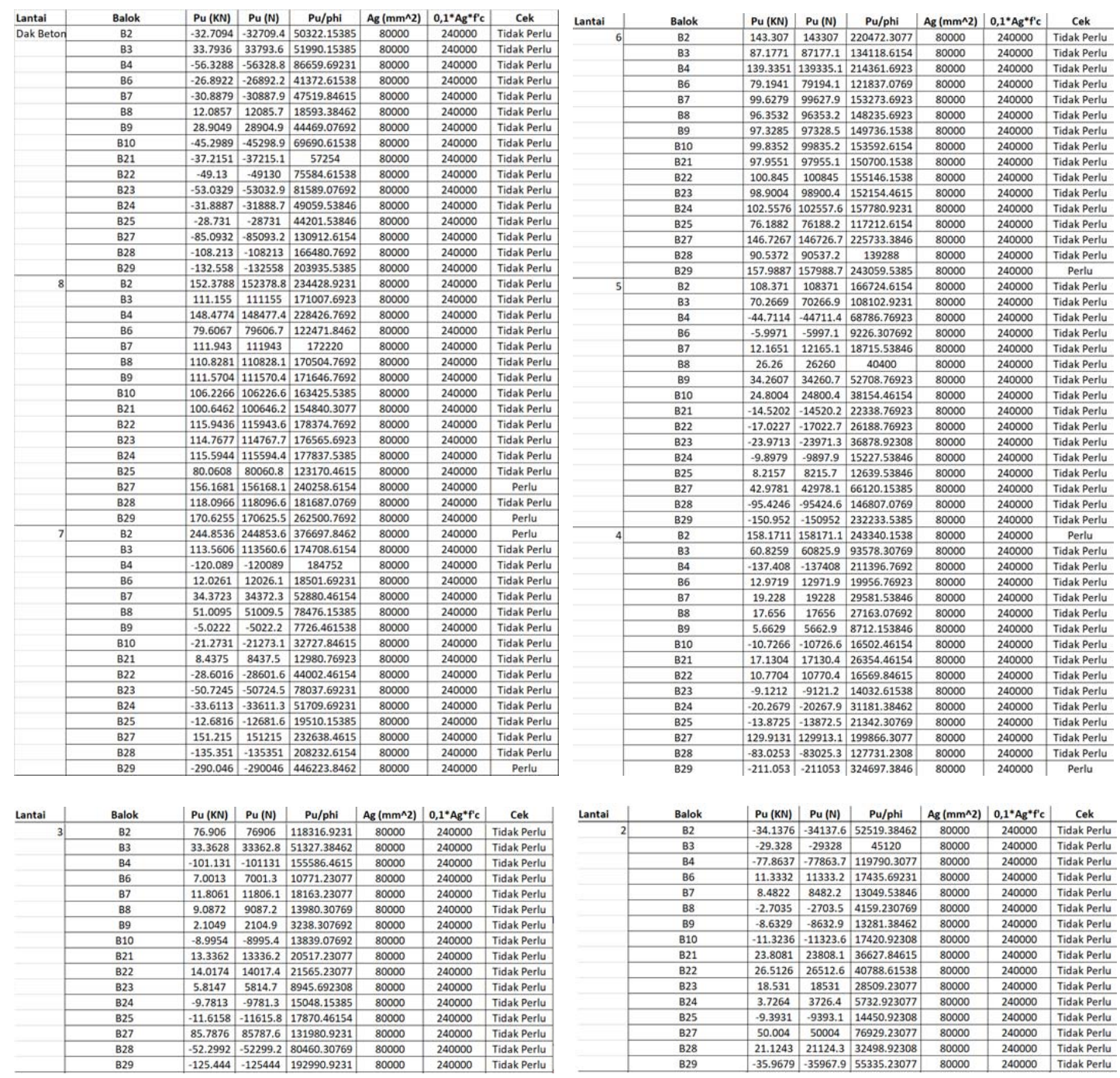

\section{KESIMPULAN DAN SARAN}

\section{Kesimpulan}

Dari penilian yang sudah penulis lakukan dapat disimpulkan sebagai berikut.

1. Hasil analisis program ETABS terhadap gaya aksial dan momen yang terjadi di sekitar elemen balok kolektor menunjukan bahwa :

- Pada balok kolektor akibat beban gempa terkombinasi arah X, hampir tidak diperlukannya tulangan longitudinal pada semua balok, kecuali balok B32, B34, B57, B59 pada lantai 8, kemudian balok B32, B57, B59 pada lantai 4, 6, dan 7. Sehingga untuk menghitung tulangan longitudinal, balok-balok tersebut harus dianggap sebagai elemen kolom.

- Pada balok kolektor akibat beban gempa terkombinasi arah Y, hampir tidak diperlukannya tulangan longitudinal pada semua balok, kecuali balok B27, B29 pada lantai 8, kemudian balok B2, B29 pada lantai 4, dan 7, serta balok b29 pada lantai 6. Sehingga untuk menghitung tulangan longitudinal, balok-balok tersebut harus dianggap sebagai elemen kolom.

2. Hasil analisis section cut program ETABS terhadap momen yang terjadi di sekitar elemen chords, baik beban gempa terkombinasi akibat arah $\mathrm{X}$ maupun $\mathrm{Y}$ menunjukan diperlukannya tulangan pada bagian tarik (tension) elemen chords sedangkan pada bagian tekan (compression) tidak diperlukan tulangan dikarenakan model bangunan merupakan bangunan beraturan. 
3. Hasil analisis section cut program ETABS terhadap gaya geser yang terjadi di diafragma, baik beban gempa terkombinasi akibat arah X maupun Y menunjukan tidak diperlukannya tulangan geser dikarenakan gaya geser luar terfaktor $\left(\frac{V u}{\phi}\right)$ yang terjadi disemua lantai kurang dari gaya geser penampang $(\mathrm{Vn})$.

\section{Saran}

1. Diperlukan penelitian lebih lanjut mengenai diafragma pada model bangunan yang memiliki ketidakberaturan karena pada penelitian ini model bangunan yang digunakan hanya sebatas pada bangunan beraturan dengan bangunan 8 lantai.

2. Diperlukan penelitian lebih lanjut mengenai diafragma pada model bangunan yang memiliki pelat openings karena pada penelitian ini model bangunan yang digunakan memiliki pelat utuh.

3. Diperlukan penelitian lebih lanjut mengenai analisis pengaruh variasi posisi dan dimensi shearwall terhadap gaya dan momen yang terjadi di daerah sekitar elemen chords dan elemen kolektor.

\section{DAFTAR PUSTAKA}

Adil, V. A. 2017. Analisis Statik dan Dinamik Pada Struktur Bangunan Bertingkat Dengan Variasi Sudut Dalam Horizontal. Jakarta.

Budiono, Bambang. "Design of 41 Story Earthquake Resistant Building With Dual System in Jakarta” in Workshop of Seismic Design of RC Buildings with Dual System according to SDC D of SNI 1726-2012, SNI 2847-2013 and Jakarta Team of Building Structural Safety Provisions.

CSI Analysis Reference Manual for SAP 2000, ETABS, SAFE, and CSIBridge. 2016. Computers and Structures, Inc. California.

Faizah, Restu. 2015. Studi Perbandingan Pembebanan Gempa Statik Ekuivalen dan Dinamik Time History pada Gedung Bertingkat di Yogyakarta. Jurnal Ilmiah Semesta Terbuka. (5 Mei 2018).

Fauziah Nasution dan Daniel Rumbi. Perbandingan Analisis Statik Ekivalen dan Analisis Dinamik Ragam Spektrum Respons pada Struktur Beraturan dan Ketidakberaturan Massa sesuai RSNI 03-1726-2012. (5 Mei 2018).

LeGrue, J. S. 2014. Evaluation of Collector Design for Concrete Diaphragms. Tenth U.S. National Conference on Earthquake Engineering Frontiers of Earthquake Engineering. Alaska. (20 Februari 2018).

Moehle, Jack. 2014. Seismic Design of Reinforced Concrete Buildings. Mc Graw Hill Education. California.

Nisius, D. D. 2017. Evaluasi Seismik Pada Rangka Portal Struktur Beton Bertulang Dengan Menggunakan Metode Pushover Analysis. Jakarta.

Prijasambada dan Vifi Hafifah. Analisa Gaya Diafragma, Kord, dan Kolektor pada Bangunan Gedung sesuai dengan SNI 1726:2012. Universitas Persada Indonesia, YAI. (6 Mei 2018).

Setiawan, Agus. 2016. Percancangan Struktur Beton Bertulang. Erlangga. Jakarta.

Standar Nasional Indonesia. 2012. Tata Cara Perencanaan Ketahanan Gempa untuk Struktur Bangunan Gedung dan Non Gedung. Badan Standarisasi Nasional. Bandung.

Standar Nasional Indonesia. 2013. Persyaratan Beton Struktural untuk Bangunan Gedung. Badan Standarisasi Nasional. Bandung.

Standar Nasional Indonesia. 2013. Beban Minimum untuk Perancangan Bangunan Gedung dan Struktur Lain. Badan Standarisasi Nasional. Bandung.

Untario, Edward. 2017. Perbandingan Analisis Statik dan Dinamik Pada Struktur Dengan Variasi Ketidakberaturan Massa Berdasarkan SNI 03-1726-2012. Jakarta. 